\title{
Utilization of New Activated Carbon Derived from Oak Leaves for Removal of Crystal Violet from Aqueous Solution
}

\author{
Mohamed Sulyman ${ }^{1 * *}$, Jacek Namiesnik ${ }^{1 *}$, Andrzej Gierak ${ }^{2}$ \\ ${ }^{1}$ Chemical Faculty, Gdańsk University of Technology, Narutowicza 11/12, 80-233 Gdańsk, Poland \\ ${ }^{2}$ Department of Physical Chemistry, Jan Kochanowski University, Poland
}

Received: 20 May 2014

Accepted: 30 June 2014

\begin{abstract}
Significant negative environmental impact has been noticed at the campus garden of Gdańsk University of Technology in Gdańsk, Poland, when the withered leaves of Quercus robur Oak Tree (OL) cover large areas at such places. In this regard, an attempt has been made to recycle the most abundant agricultural leaf waste into a high quality local activated carbon (LAC) for use in the decolorization processes of dye industrial wastewater. A novel AC prepared from OL was studied for removing of crystal violet dye (CV) from aqueous solution under various experimental conditions. The effect of an OLAC adsorbent dose (5-30 mg/25ml), pH (3.09.0), two levels of shaking (90 and $130 \mathrm{rpm}$ ) under different contact times as compared to the sorption process at soaking in a beaker for one day, and CV initial concentrations $(5-40 \mathrm{mg} / \mathrm{l})$ were all studied in a batch mode process. The sorption exhibited high efficiency for $\mathrm{CV}$ adsorption and the equilibrium state could be achieved in 20 minutes for the different $\mathrm{CV}$ initial concentrations. $\mathrm{CV}$ uptake was proved to increase with the increase in OLAC dose, $\mathrm{pH}$, shaking rate, contact time, and $\mathrm{CV}$ initial concentration. The applicability of Lungmuir and Freunflich isotherm equations was investigated. The Freundlich isotherm exhibited a better fit with the experimental data with linear regression value $\left(\mathrm{R}^{2}\right)$ of 0.9937 , although the isotherm parameters of the Langmuir isotherm also indicate favourable adsorption. The maximum capacity $\left(\mathrm{q}_{\mathrm{m}}\right)$ obtained from Langmuir isotherm model was $41.15 \mathrm{mg} / \mathrm{g}$ for CV. The results of this study demonstrated the feasibility of applying the low cost and abundantly available $\mathrm{OL}$ as a raw material for the preparation of high-quality AC the for removal of $\mathrm{CV}$ from aqueous solution.
\end{abstract}

Keywords: activated carbon, adsorption, batch mode, crystal violet, oak leaves

\section{Introduction}

Dyes are known to be particularly dangerous organic compounds for the environment [1]. It is estimated that approximately 40,000 dyes and pigments are listed, which consists of over 7,000 different chemical structures [2]. They usually have synthetic origin and complex aromatic

*e-mail: chemanal@pg.gda.pl

**e-mail: mohsulym76@yahoo.com molecular structures, which make them more stable and more resistant to biodegradation processes [3]. It was also estimated that about 10,000 of various commercial dyes and pigments exist and over $7 \times 10^{5}$ tons are produced annually worldwide [4]. The dyes lost in the effluent during the dying process amount to between $10-15 \%[5,6]$. Latest reports indicated that approximately $12 \%$ of the synthetic dyes are unintentionally lost during manufacturing and processing operations. However, the industrial wastewater receives approximately $20 \%$ of these lost dyes $[7,8]$. 
Dyes are found in the wastewater streams of industrial processes, including paint manufacture, dying, textiles, papers, and more [9]. Therefore, it is environmentally very important for industries in concern to remove the synthetic dyestuff from the wastewater before discharging it into any natural receptor waters. Various techniques have been employed for the removal of dyes from wastewaters [1015]. Among these processes, adsorption currently appears to be the best in order to remove colors from wastewater [16].

Another problem facing the environment is the huge quantities of the withered leaves falling from the trees annually in autumn. The fallen leaves usually create piles in public gardens and national woods and thus pose a great panic to the environment which will definitely have a substantial impact on people's health. They become habitats and breeding sites for insects, rodents, and other creatures, resulting in further environmental damage and health problems to domestic animals and humans. In cities, the cesspits constructed particularly for the discharge of rain water are often blocked by the fallen leaves (Fig. 1). In addition, the piles of leaves also create a potential fire hazard that can damage hundreds of hectares of woods annually, and release gases as well as large plumes of black smoke and other contaminants into the atmosphere. It was reported that in the United States some 30 million tons of leaves are collected and burned every year [17].

In recent years, special attention has been focused on the utilization of natural, abundant, and eco-friendly sor-
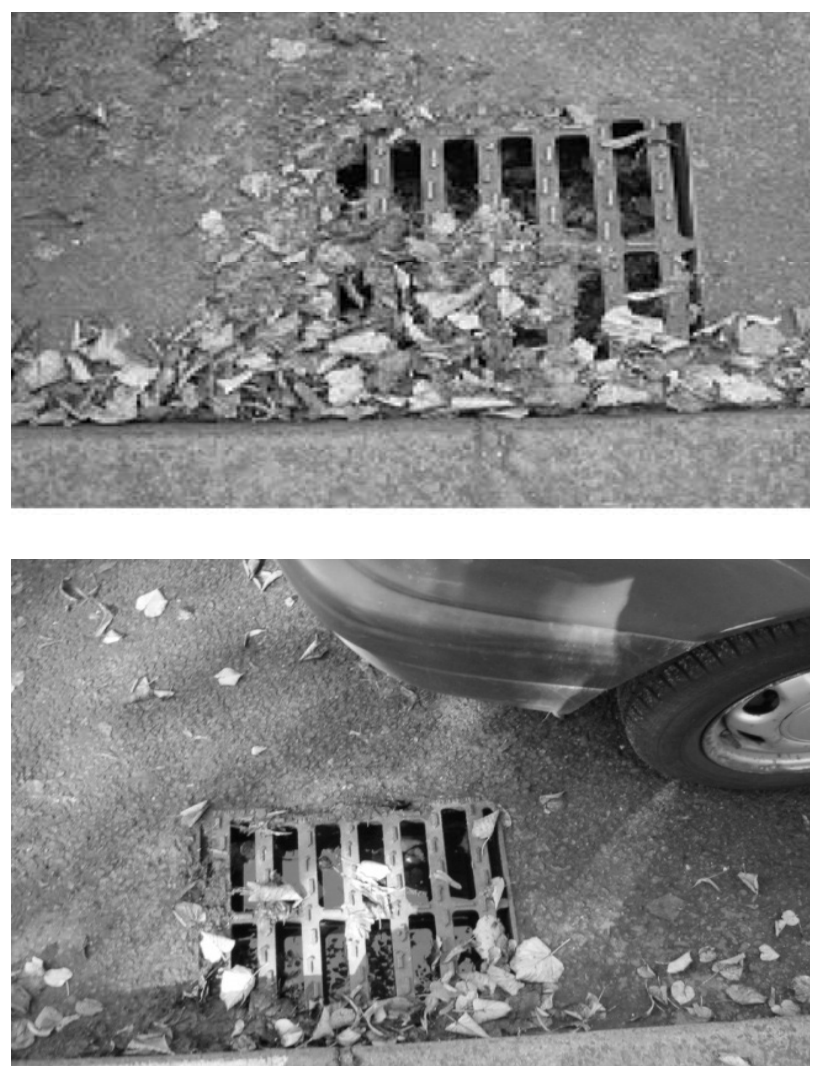

Fig. 1. Fallen withered Oak leaves blocking rain water discharge cesspits found at the side of roads (taken by researcher Nov. 2012). bents to replace conventional and expensive sorbents $[18$, 19]. AC's represent such an example. They are mostly manufactured and developed by the pyrolysis of carbonaceous materials of plants and agricultural residues (wastes) [20] such as coconut shells [21], walnut shells [22], palm shells [23], date stones [24, 25], almond shells [26], used tea leaves [27], and cotton stalks [28], followed by either physical or chemical activation of chars obtained from them [29].

Dead tree leaves such as Posidonia oceanic L. [30], pine needles [31], spent tea leaves [27], and Acacia niloti$c a$ L. leaves [32] have been proposed and reported as simple and abundant agro-precursors for the study on removal of dyes from aqueous solutions [33]. The use of high-incarbon content plant leaves in manufacturing $\mathrm{AC}$ has been suggested to attain a significant positive ecological impact and a simple and cheap method for the adsorption of organics such as dyes from aqueous solutions [33, 34]. The applications of ACs are involved in many fields that can be used as a green adsorbents for separation, purification, decolorization and deodorization, of vegetable oils and fats, water purification and pollution treatment, air and gas purification (cigarette filters, motor vehicles exhaust control), and food and pharmaceutical industries [35-37]. Also at some scientific laboratories such as biological, medical, pharmaceutical, and chemical laboratories at universities when dyes were involved in research [27].

Unpleasant ecological impacts have been experienced at public gardens and woods of Gdańsk city in Poland in winter and autumn seasons when leaves of most abundant and widely planted Quercus robur oak trees are withered and fall in vast quantities. In this work, an attempt will be made to recycle a certain quantity of oak tree leaf waste into a high-quality and eco-friendly local activated carbon produced by chemical activation to adsorb CV dye; it is chosen as a model for basic dyes type.

\section{Materials and Methods}

\section{Preparation of Activated Carbon}

Dry Quercus robur OL as precursors were gathered during the fall season from the campus gardens of Gdańsk University of Technology in Poland (Fig. 2), put into plastic bags, and immediately transported to the laboratory. The leaves were washed with boiling water and soap to remove impurities and undesirable materials, washed several times with distilled water, and dried at room temperature for 5 days and in the oven at $100^{\circ} \mathrm{C}$ for 24 hours. After drying, leaves were activated by impregnating them with phosphoric acid ( $65 \%$ by weight) at a weight ratio of $1: 1$ (Leaves:acid). Next, the impregnated leaves of $150 \mathrm{~g}$ were packed in $15 \times 15 \mathrm{~cm}^{2}$ aluminum foil which was then placed inside a furnace. The temperature was raised at heating rate of $10^{\circ} \mathrm{C} / \mathrm{min}$ from room temperature to $650^{\circ} \mathrm{C}$ for $60 \mathrm{~min}$. After cooling, the sample was washed thoroughly using hot distilled water until $\mathrm{pH}$ reached 7. Finally, the carbonized leaves were ground manually and passed through a $0.4 \mathrm{~mm}$ 


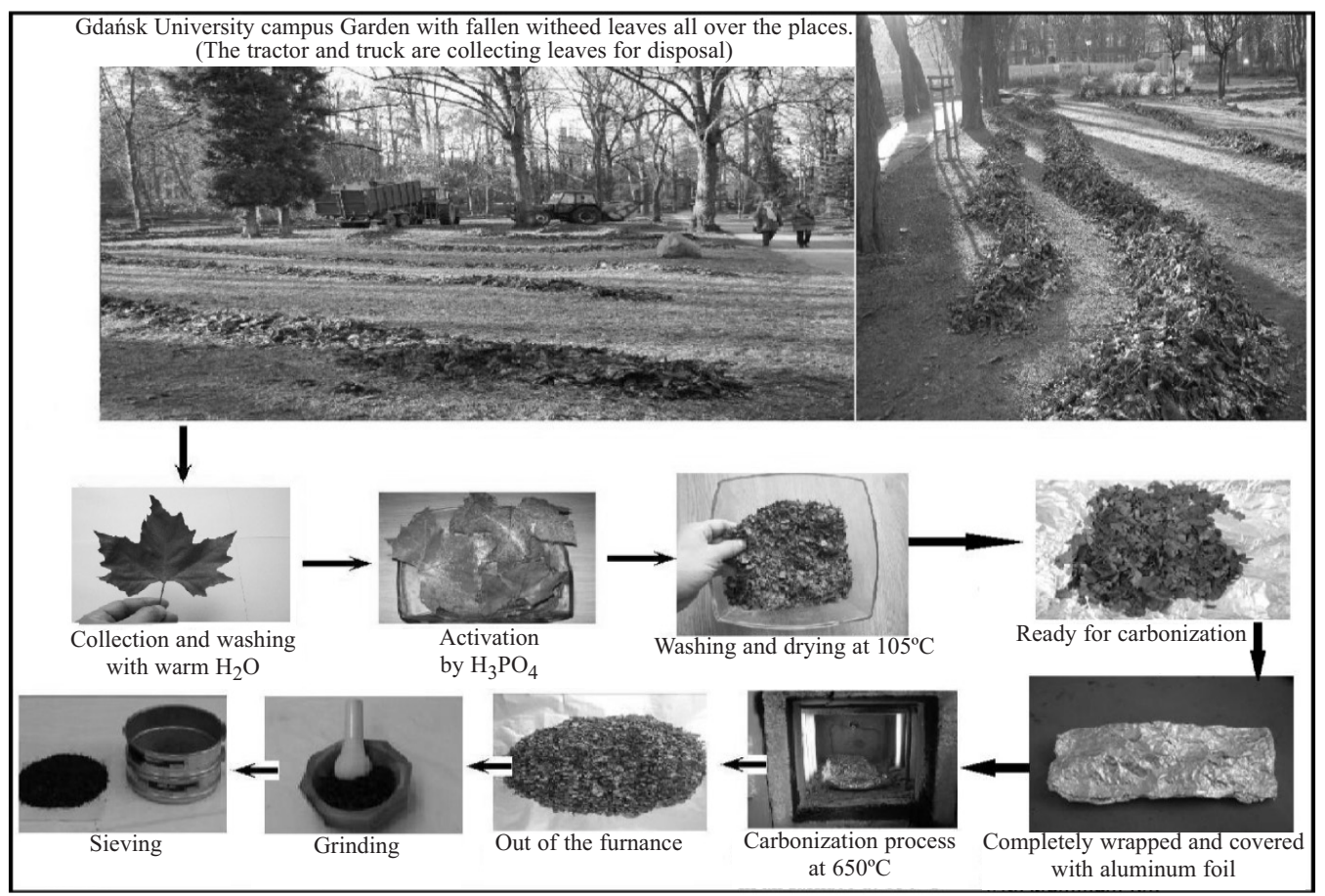

Fig. 2. Step-by-step illustration of AC preparation of withered oak leaves.

sieve plate to produce carbon of uniform size. The yield of OLAC was calculated by formula (1).

$$
\text { Yield }=\frac{\text { Weight of final product }}{\text { Weight of initial Sample }} \times 100
$$

\section{Preparation of CV Dye Solutions}

$\mathrm{CV}$ is the triphenylmethyl cation $\left(\mathrm{C}_{22} \mathrm{H}_{30} \mathrm{~N}_{3} \mathrm{Cl}\right.$; molecular weight $408 ; \lambda_{\max } 584 \mathrm{~nm}$ ). It is used in this study as a model molecule for organic pollutants in general and basic dyes in particular, and thus no further purifications were needed. The molecular structure of $\mathrm{CV}$ dye is shown in Fig. 3. A stock solution of CV $(1000 \mathrm{mg} / \mathrm{l})$ was prepared by dissolving accurately the weighed quantity of the dye in double-distilled water. Experimental dye solutions of the desired concentration were obtained by successive dilutions. All chemicals used throughout this study were of analytical-grade reagents.<smiles>CN(C)c1ccc(C(c2ccc(N(C)C)cc2)c2cc[n+](C)cc2)cc1</smiles>

Fig. 3. Molecular Structure of Crystal Violet [32].

\section{Instrumentation}

Unknown concentrations of CV dye were determined by finding the absorbance at the characteristic wavelength using a double beam UV/visible spectrophotometer (Specord 205, UV-Analytikjena, Germany). The pH measurements were carried out using a 740 Inolab WTW model $\mathrm{pH}$ meter with a SenTix $20 \mathrm{pH}$ model double electrode. A digital shaker (GFL 3005 model, Germany) was used for all batch mode adsorption experiments. A Tensor 27 Bruker, USA Fourier Transform Infrared Spectroscopy (FT-IR) for the characterization of the OLAC functional groups at the range of 450-4000 $\mathrm{cm}^{-1}$ before and after batch mode adsorption process for $\mathrm{CV}$ dye.

The Brunauer-Emmett-Teller (BET) nitrogen adsorption technique is conducted to evaluate the surface area and pore volume of the non-activated carbon OL, which involved the application of physical adsorption of nitrogen at $77 \mathrm{~K}$ in a Micromeritics ASAP 2020 apparatus, USA. The content of $\mathrm{C}, \mathrm{H}, \mathrm{N}$, and $\mathrm{O}$ atoms with the non-activated OL was determined by a FLASH $2000 \mathrm{CHNS} / \mathrm{O}$ analyzer (Thermo Scientific, USA). Thermo-gravimetric experiments were recorded on a TA instrument SDT Q 500 operating under nitrogen with a flow rate of $100 \mathrm{ml} / \mathrm{min}$ through a furnace. Samples weighted about $10 \mathrm{mg}$, varying heating rates of $10^{\circ} \mathrm{C} / \mathrm{min}$, and temperature range of 30$800^{\circ} \mathrm{C}$. Finally, a scanning electron microscope (Quanta FEG, USA) was used to study the surface of the OLAC at very high magnifications.

\section{Adsorption Experiment}

Batch mode sorption experiments were performed in a shaker at a constant shaking rate of $130 \mathrm{rpm}$, contact time 
of 20 minutes, and room temperature of $25 \pm 2^{\circ} \mathrm{C}$ for different $\mathrm{pH}$ of solutions (3.0-9.0), and using $100 \mathrm{ml}$ Erlenmeyer flasks. All sorption experiments were conducted by mixing different quantities $(5-30 \mathrm{mg}$ ) of OLAC with CV solutions containing different initial concentrations of (5-40 mg/l).

After termination of the adsorption experiments, the remaining concentration of $\mathrm{CV}$ in each sample was determined by UV spectroscopy after filtering the adsorbent with whatman filter paper to make it carbon free. The amount of adsorption at equilibrium $q_{e}(\mathrm{mg} / \mathrm{g})$ was calculated as follows (2):

$$
q_{e}=\left(C_{0}-C_{e}\right) \times(V / M)
$$

...where $C_{0}$ and $C_{e}(\mathrm{mg} / \mathrm{l})$ are the liquid-phase concentration of dye at initial and final, respectively. $V(1)$ is the volume of the solution, and $M(\mathrm{~g})$ is the mass of dry sorbent used.

The percentage sorption (\%) was calculated using the following equation (3):

$$
\% \text { sorption }=\left\{\left(C_{0}-C_{e}\right) / C_{0}\right\} \times 100
$$

In this study, variations in adsorbent dose, shaking rate at different contact times, initial $\mathrm{CV}$ concentrations, and $\mathrm{pH}$ and the investigations of their effects were all aimed at by the study.

\section{Isotherm Studies}

Adsorption isotherms correlate the equilibrium adsorption data with different isotherm models; Langmuir and Freundlich isotherms are the most frequently used equations to study the nature of isotherms [38-40]. In fact, the isotherm models describe the relationship between the adsorbate and the adsorbent and how they interact with each other and are critical for optimizing the use of the adsorbent.

The Langmuir isotherm model represents the simplest in all known isotherm models for monolayer adsorption. It is developed by assuming that the force of interaction between the adsorbed molecules is negligible, that a fixed number of accessible sites is available on the adsorbent surface in which these sites are energetically equivalent, and once an adsorbate molecule occupies a site, no further adsorption takes place [38-41]. In other words, the Lungmuir presumes a specific homogenous type of adsorption, i.e., once a molecule of $\mathrm{CV}$ takes an active site, no other can take the same site. The linear form of the Langumir model is used as in the following equation (4):

$$
C_{e} / q_{e}=1 / q_{\max } b+C_{e} / q_{\max }
$$

...where $q_{e}$ is the solid phase adsorbate (OLAC) concentration at equilibrium $(\mathrm{mg} / \mathrm{g}), C_{e}$ is the equilibrium $\mathrm{CV}$ concentration (mg/l), $q_{\max }$ is the maximum adsorption capacity corresponding to complete monolayer adsorption $(\mathrm{mg} / \mathrm{g})$, and $b$ is the Langmuir isotherm constant. The slope and the intercept of linear plots of $C_{e} / q_{e}$ vs. $C_{e}$ are used to calculate the constant parameters of $q_{\max }(\mathrm{mg} / \mathrm{g})$ and $b$.

In contrast, the Freundlich isotherm model has been widely used for many years to describe experimental adsorption data. The model assumes that adsorption takes
Table 1. CHNO elemental analysis.

\begin{tabular}{|c|c|}
\hline Atom & Content in percentage, (\%) \\
\hline $\mathrm{C}$ & 47.55 \\
\hline $\mathrm{H}$ & 5.23 \\
\hline $\mathrm{N}$ & 3.79 \\
\hline $\mathrm{O}$ & 38.43 \\
\hline
\end{tabular}

Table 2. Textural characteristics of the produced activated carbon derived by oak leaves (without activation).

\begin{tabular}{|c|c|c|c|c|}
\hline $\begin{array}{c}\text { Surface } \\
\text { area } \\
(\mathrm{BET}), \\
\mathrm{m}^{2} / \mathrm{g}\end{array}$ & $\begin{array}{c}\text { Single-point } \\
\text { adsorption } \\
\text { total volume } \\
\text { of pores, } \\
\mathrm{cm}^{3} / \mathrm{g}\end{array}$ & $\begin{array}{c}\text { BJH } \\
\text { adsorption } \\
\text { average } \\
\text { pore diame- } \\
\text { ters, } \mathrm{nm}\end{array}$ & $\begin{array}{c}\text { BJH } \\
\text { desorption } \\
\text { average } \\
\text { pore diame- } \\
\text { ters, } \mathrm{nm}\end{array}$ & $\begin{array}{c}\mathrm{t} \text {-plot } \\
\text { micropore } \\
\text { volume, } \\
\mathrm{cm}^{3} / \mathrm{g}\end{array}$ \\
\hline 4 & 0.06 & 0.7 & 4.1 & 0.02 \\
\hline
\end{tabular}

Table 3. Compression of surface area of some activated carbons.

\begin{tabular}{|c|c|c|}
\hline Activated carbon type & SBET $\left(\mathrm{m}^{2} / \mathrm{g}\right)$ & Reference \\
\hline $\mathrm{AC}-$ Hazelnut shell & 5 & {$[43]$} \\
\hline $\mathrm{AC}-$ Hazelnut shell & 10.1 & {$[44]$} \\
\hline $\mathrm{AC}-$ Hazelnut husk & 4.31 & {$[45]$} \\
\hline $\begin{array}{c}\mathrm{AC}-\text { Posidonia oceanic }(\mathrm{L} .), \\
0 \% \text { activation }\end{array}$ & 38.9 & {$[46]$} \\
\hline $\begin{array}{c}\text { AC - from Oak leaves, } \\
0 \% \text { activation }\end{array}$ & 4 & $\begin{array}{c}\text { Present } \\
\text { study }\end{array}$ \\
\hline
\end{tabular}

place on a heterogeneous surface, and can be used for nonideal adsorption [41, 42]. The linear form of Freundlich is expressed as follows (5):

$$
\log q_{e}=1 / \mathrm{n} \log C_{e}+\log K_{f}
$$

...where $K_{f}$, and n are Freundlich constants with " $n$ " giving an indication of the facility with which the adsorption process takes place, $K_{f}(\mathrm{~L} / \mathrm{mg})$ is the adsorption capacity of the adsorbent $\mathrm{AC}$.

\section{Results and Discussion}

\section{Adsorbent Characteristics}

\section{Physico-Chemical Analysis of the Adsorbent}

The $\mathrm{C}, \mathrm{H}, \mathrm{N}, \mathrm{O}$ contents of the non-activated $\mathrm{OL}$ are shown in Table 1, while the textural characteristics of OLAC are shown in Table 2.

Table 3 provides surface areas of some other activated carbon obtained from different agricultural by-products/wastes. The results obtained in this research study can be comparable to those values reported in literature. 

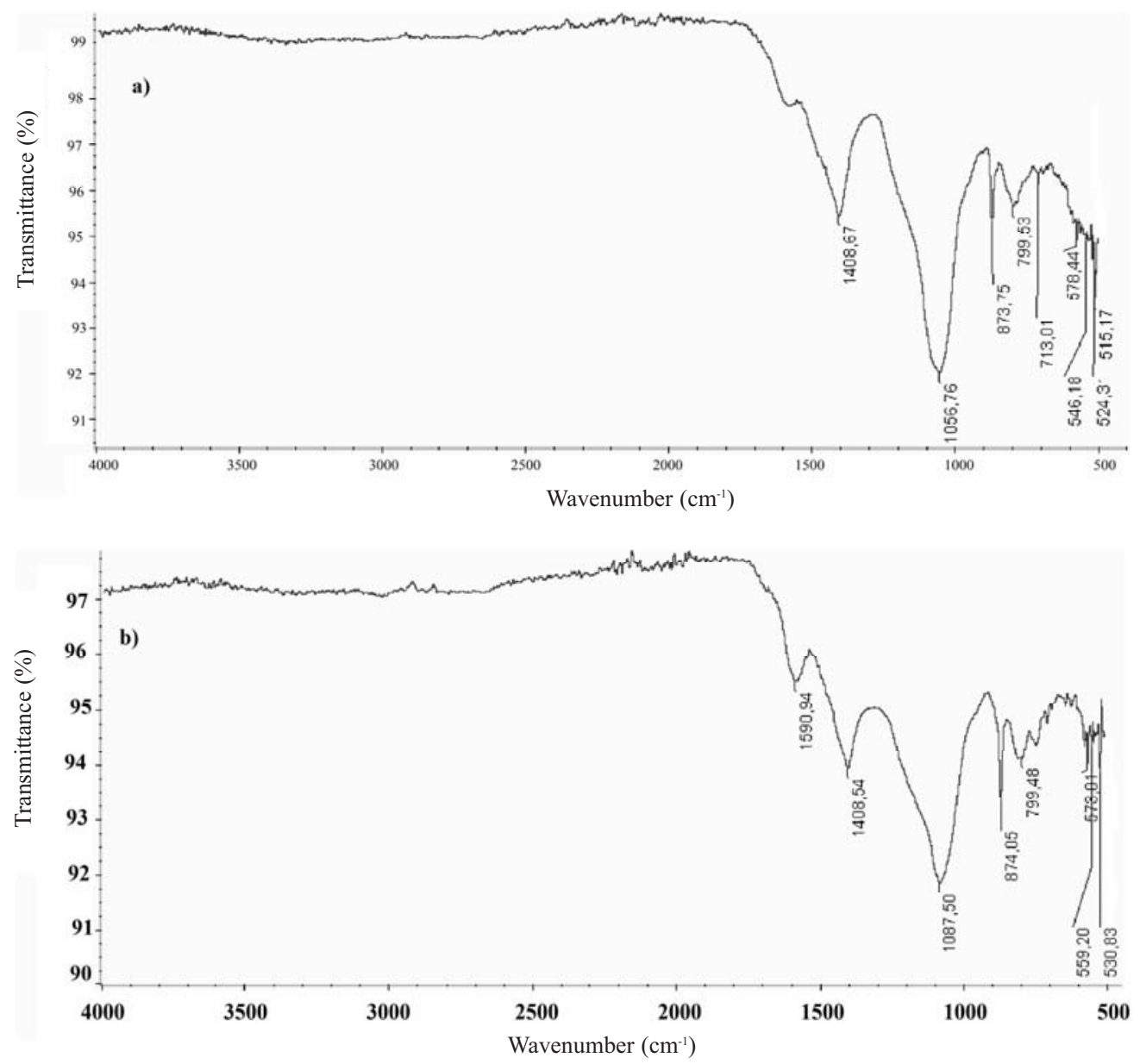

Fig. 4. FTIR spectrum of OLAC adsorbent before (a) and after the batch mode sorption process (b).

\section{FTIR Analysis}

The FTIR spectra can provide valuable information about the chemical composition of the materials. Fig. 4 shows the comparison FTIR spectra of AC obtained from OL before and after batch mode sorption. The ACOL spectrum in Fig. 4 (a) shows a peak at $1,403.54 \mathrm{~cm}^{-1}$, representing $\mathrm{CH}_{2}$ deformation [47]. Another important band is observed at $1,087.50 \mathrm{~cm}^{-1}$, which could be assigned to C$\mathrm{OH}$ stretching vibration deformation [48]. While the OLAC spectrum in Fig. 4 (b) demonstrates the AC after batch mode, sorption shows the presence of a new peak at 1,590.94 and a little shift to almost all aforementioned peaks, in addition to the disappearance of a peak at 713.01 $\mathrm{cm}$ (Fig. 4 a). Comparing the two figures, one can conclude that some of these peaks were shifted or disappeared and new peaks were detected. These findings of changes observed in the spectra indicate the possible involvement of those functional groups on the surface of the OLAC in the sorption process.

\section{Thermogravimetric Analysis (TGA)}

Fig. 5 shows the percentage weight loss during TGA for Oak leaves. Two major weight losses took place in this graph. The first range of decomposition happened at approximately 50 to $150^{\circ} \mathrm{C}$, which represents almost $7.0 \%$ weight lost. This is most possibly due to the moisture released by the sample during heating. The largest weight loss occurred at temperature range of about 450 to $700^{\circ} \mathrm{C}$ due to decomposition of chemically bonded water, cellulose, hemicellulose, and lignin to carbons [49-51]. These types of decompositions probably explain the reason behind the absence of any intensive peaks at the region between $400 \mathrm{~cm}^{-1}$ to at least $1,700 \mathrm{~cm}^{-1}$ on the FTIR spectrum (Fig. 4). Further heating above $700^{\circ} \mathrm{C}$ reveals a lowering trend of weight loss, indicating the formation of volatile materials like $\mathrm{CO}, \mathrm{CO}_{2}$, etc. $[29,52]$.

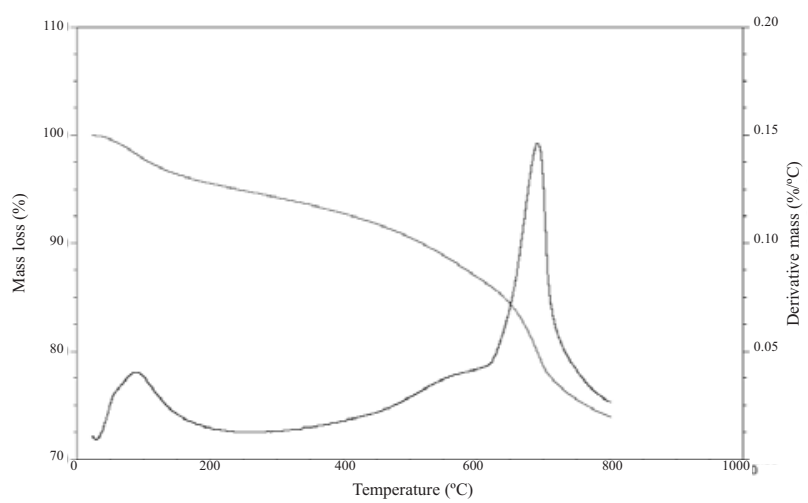

Fig. 5. TGA experiment at $650^{\circ} \mathrm{C}$, initial weight of adsorbent $10 \mathrm{mg}$. 

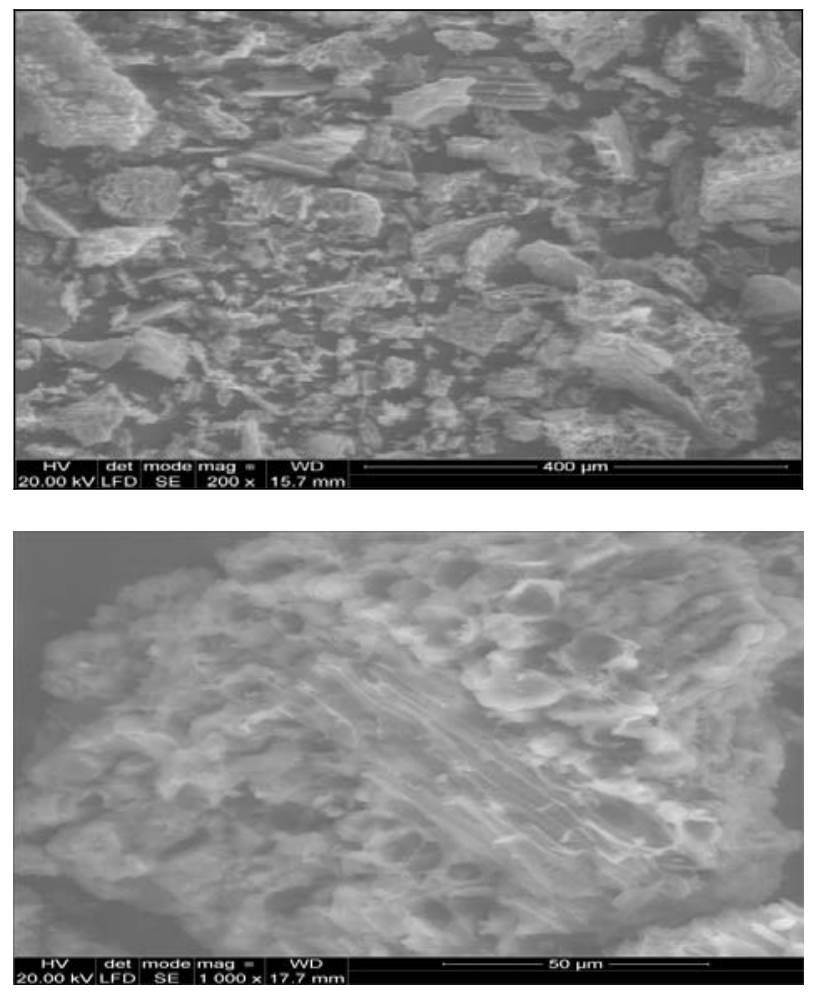

Fig. 6. a) SEM images of the adsorbent obtained at a magnification of 200 times, b) SEM images of adsorbent obtained at a magnification of 1000 times.

\section{SEM Analysis}

Scanning electron microscopy (SEM) was used in order to obtain information about the surface area morphology of the activated carbon. The surface texture of the sorbent is shown in (Fig. 6a). It can be seen from the figure that particles are almost irregular in shape. On further magnification, as shown in (Fig. 6b), the surface can be seen to seem to posses a porous texture as is clear in the image obtained with $1000 \times$ magnification.

\section{Effect of Adsorbent Dose}

The effect of adsorbent ACOL dosage on CV dye sorption is shown in Fig. 7. The OLAC adsorbent dose was

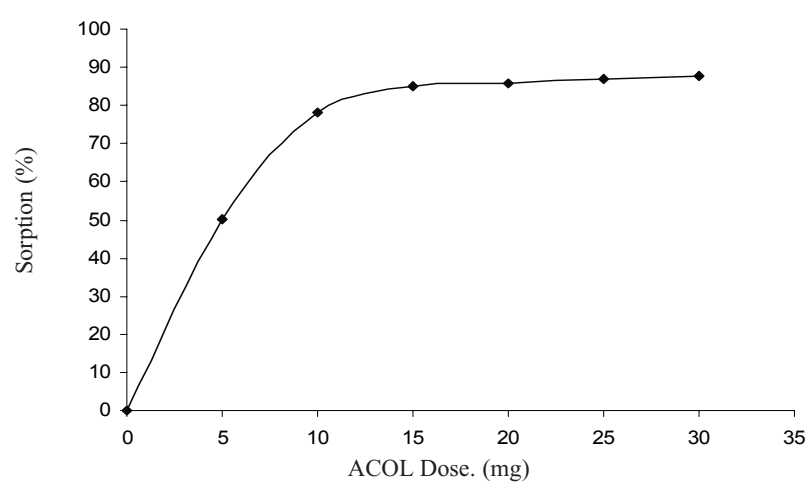

Fig. 7. $\mathrm{CV}$ adsorption as a function of $\mathrm{AC}$ of Oak leaves amounts $\left(25 \mathrm{ml}\right.$ of $40 \mathrm{mg} / \mathrm{l}$ of CV, temp. $25^{\circ} \mathrm{C}$ and $\mathrm{pH} 7.0$, shaking rate $130 \mathrm{rpm}$, contact time of $20 \mathrm{~min}$.).

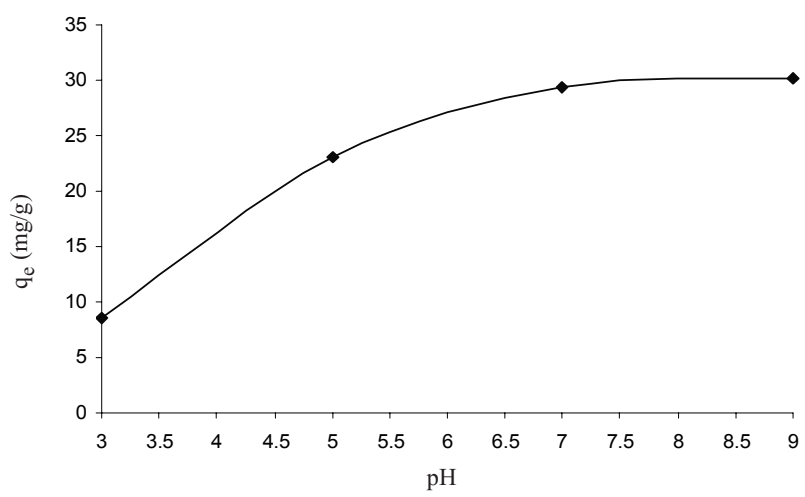

Fig. 8. The effects of $\mathrm{pH}$ on the removal of $\mathrm{CV}$ basic dye by the OLAC.

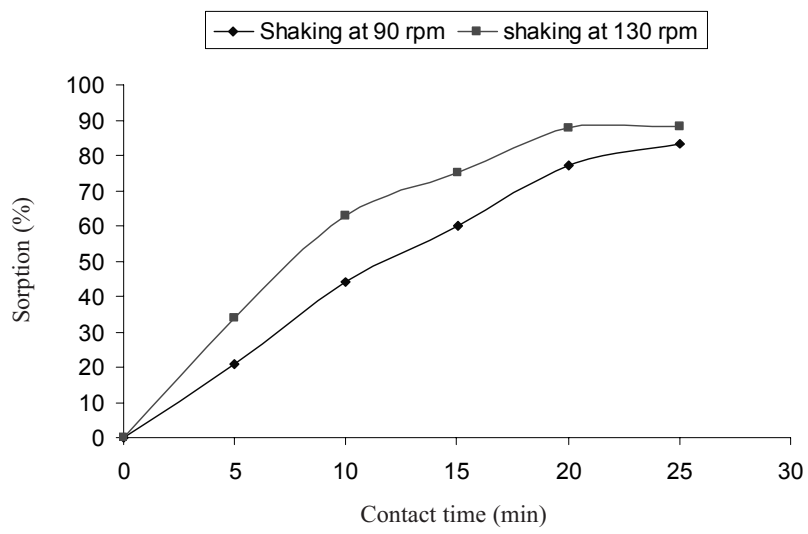

Fig. 9. The effects of Shaking on the adsorption equilibrium time at two different speeds (90, and $130 \mathrm{rpm}$ ).

between 5 and $30 \mathrm{mg}$ for an initial CV concentration of 40 $\mathrm{mg} / \mathrm{l}$. The sorption process was carried out at constant $\mathrm{pH}$ of 7.0, shaking rate of $130 \mathrm{rpm}$, contact time of $20 \mathrm{~min}$, and working solution temperature of normal room temperature. The obtained results showed that as the adsorbent ACOL dose is increased from $5 \mathrm{mg}$ to $30 \mathrm{mg}$, the percentage removal of $\mathrm{CV}$ dye increases from $50.25 \%$ to $87.8 \%$. The residual $\mathrm{CV}$ in the aqueous solution decreased from 40.0 $(\mathrm{mg} / \mathrm{l})$ to $4.9(\mathrm{mg} / \mathrm{l})$. This can be attributed to the increase of the available sorption active sites in OLAC adsorbents with increase in quantity (weight) of OLAC [32, 53-57].

\section{Effect of $p H$}

$\mathrm{pH}$ is very effective in protonation of the three amino groups of CV dye molecule. And the number of the positive charges of these three amino groups decreases to none with the increase of $\mathrm{pH}$ towards alkalinity. A number of $\mathrm{CV}$ dye solutions with initial concentration of $30 \mathrm{mg} / \mathrm{l}$ were adjusted to 3.0, 5.0, 7.0, and 9.0. Each solution has been characterized with different color as a result of different charged states. The CV batch mode adsorption was carried out at room temperature of $25^{\circ} \mathrm{C}$, shaking rate of $130 \mathrm{rpm}$, and contact time of $20 \mathrm{~min}$.

From Fig. 8, it was observed that the uptake capacities $\left(q_{e}\right)$ of CV increased with the increase of $\mathrm{pH}$ up to $\mathrm{pH}<7.0$. 


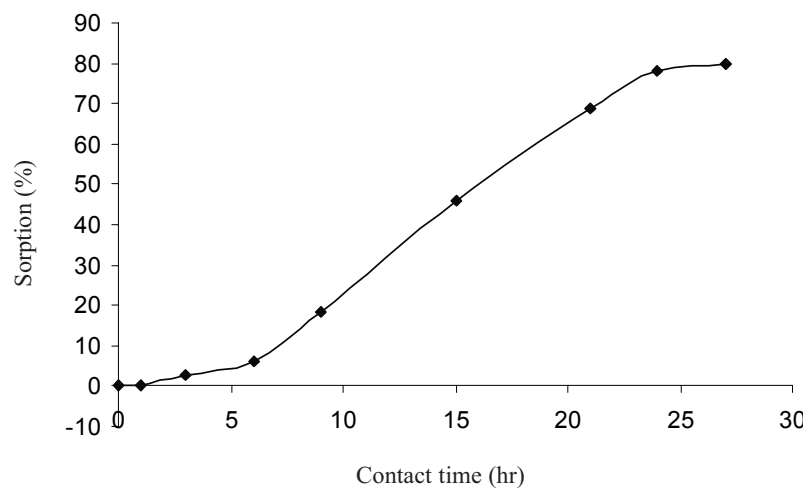

Fig. 10. The effects of contact time on $\mathrm{CV}$ adsorption by soaking at room temperature under the following parameters: $25 \mathrm{ml}$ of $30 \mathrm{mg} / 1 \mathrm{of} \mathrm{CV}, 30 \mathrm{mg}$ of OLAC adsorbent, $\mathrm{pH} 7$.

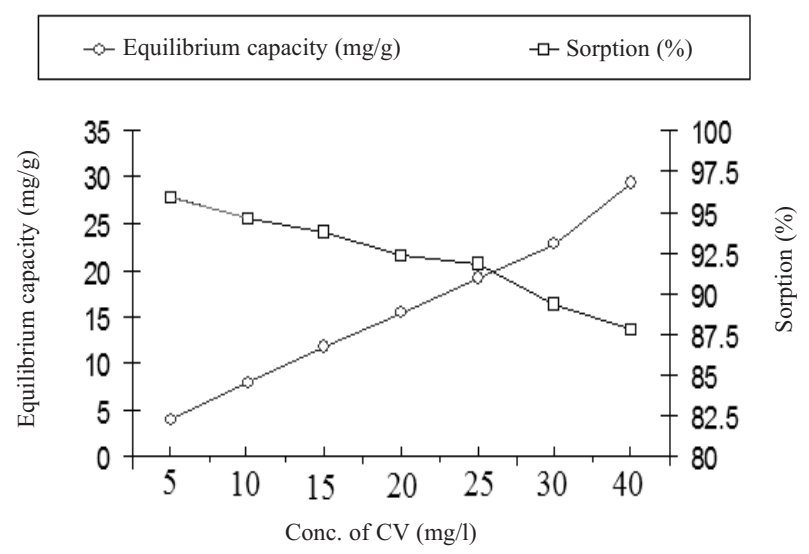

Fig. 11. Variation of $\mathrm{CV}$ adsorption as a function of $\mathrm{CV}$ concentrations $\circ$. The effect of $\mathrm{CV}$ concentrations on $\mathrm{CV}$ adsorption (percentage removal) $\square$.

In other words, the residual $\mathrm{CV}$ dye decreased with an increase in $\mathrm{pH}$ from 3.0 to $<7.0$. In contrast, above $\mathrm{pH}>$ 7.0 the $\mathrm{CV}$ residual became nearly steady. At low $\mathrm{pH}(3.0$ and 5.0) the protonation of the negatively binding active sites was enhanced by the high increase in proton $\left(\mathrm{H}^{+}\right)$and thus the number of free active sites became lower for the $\mathrm{CV}$ molecules uptake. In contrast, when the $\mathrm{pH}$ was higher $(>7.0)$ the free active sites of OLAC gradually became deprotonated (i.e negatively charged) and the electrostatic process of attraction of the cationic $\mathrm{CV}$ dye molecules became enhanced [32-34, 36, 37].

\section{Effect of Shaking and Contact Time}

The batch mode adsorption of CV dye $(30 \mathrm{mg} / \mathrm{l})$ by the ACOL adsorbent ( $30 \mathrm{mg}$ dose) has taken place by shaking the tested solutions ( $\mathrm{pH} 7)$ at two different speeds (90, and $130 \mathrm{rpm}$ ) and another time by soaking the OLAC at room temperature.

Figs. 9 and 10 demonstrate the results obtained in this part of work, and show that the uptake rate of CV dye occurred in both cases. However, the uptake by sorption process was much higher by shaking at the two levels (90 and $130 \mathrm{rpm}$ ) (Fig. 9) and less in contact time than soaking for one day (Fig. 10). Equilibrium time is an important element to study when considering an economical wastewater treatment application [58]. The equilibrium has occurred by shaking at $130 \mathrm{rpm}$ during contact time of $20 \mathrm{~min}$, leading to sorption percentage of $87.8 \%$, which can be obviously seen as shorter in contact time than the batch process conducted at $90 \mathrm{rpm}$. A similar result was obtained by the adsorption of a basic dye by Citrullus Lanatus Rind [41]. In contrast, the batch mode sorption took 2 days by soaking at room temperature, leading to a sorption percentage of 81.4. This was attributed to the fact that increasing the rate of shaking leads to an increase in transport material rate toward the adsorbent, as stated by Rammel et al. [55]. In addition, Cengiz [59] and Awala and his colleague [60] also obtained almost similar results by the adsorption of methyl violet onto dead leaves of Poisdonia Oceanica and by the adsorption of methylene blue MB onto feldspar, respectively.

\section{Effect of CV Initial Concentrations}

The initial concentration provides an important driving force to overcome all mass transfer resistance of $\mathrm{CV}$
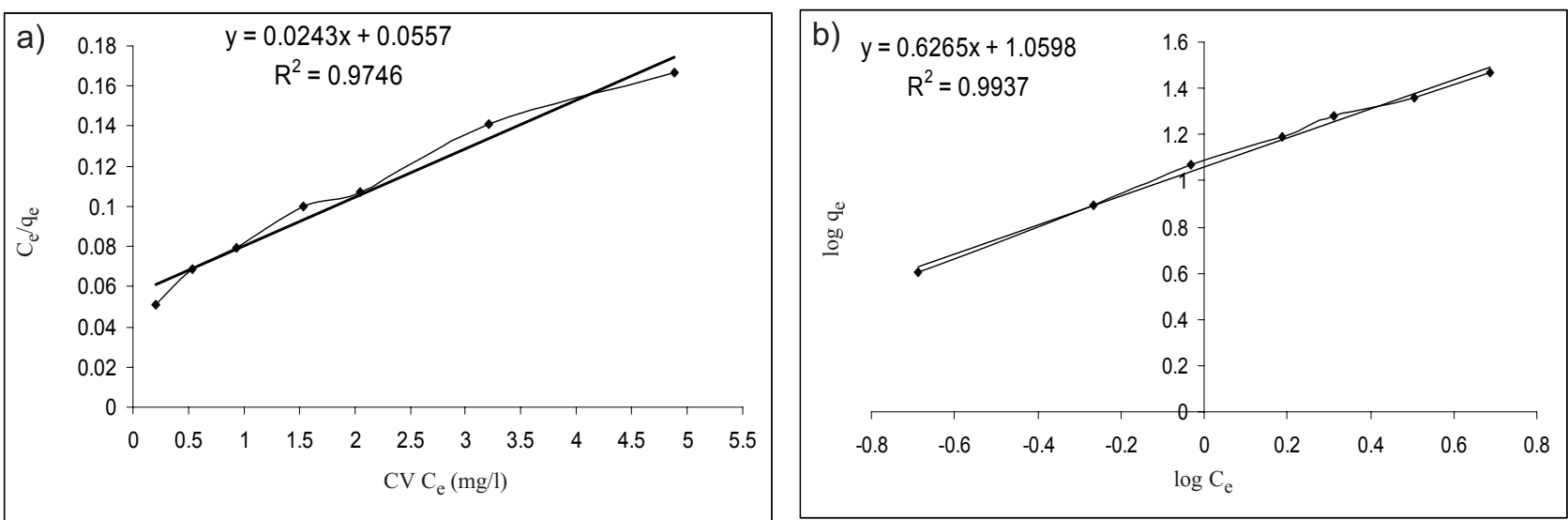

Fig. 12. Langmuir plot for CV sorption (a) and Frendlich plot for CV sorption onto ACOLadsorbent (b). 
Table 4. Langmuir and Freundlich model parameters related to the adsorption isotherm of CV onto ACOL.

\begin{tabular}{|c|c|c|c|c|c|}
\hline \multicolumn{3}{|c|}{ Lungmuir model } & \multicolumn{3}{c|}{ Freundlich model } \\
\hline$q_{\max }(\mathrm{mg} / \mathrm{g})$ & $b(1 / \mathrm{mg})$ & $\mathrm{R}^{2}$ & $K_{f}(1 / \mathrm{g})$ & $n$ & $\mathrm{R}^{2}$ \\
\hline 41.15 & 0.436 & 0.9746 & 2.89 & 1.60 & 0.9937 \\
\hline
\end{tabular}

between the aqueous and solid phases $[53,56]$. The initial CV dye concentration of $5,10,15,20,25,30$, and $40 \mathrm{mg} / \mathrm{l}$ were used at room temperature, an adsorption $\mathrm{pH}$ of 7.0, constant contact time of $20 \mathrm{~min}$ and shaking rate of $130 \mathrm{rpm}$ and in conjunction with ACOL adsorbent dose of 30 $(\mathrm{mg} / 25 \mathrm{ml})$.

The effect of initial CV concentration on the adsorption is shown in Fig. 11. It can be seen from the figure that with the increase in $\mathrm{CV}$ concentrations, the percentage removal of $\mathrm{CV}$ decreases. As seen in the figure, while the initial CV concentration increased from 5 to $40 \mathrm{mg} / \mathrm{l}$, the percentage CV removal by AC decreased from $95.9 \%$ to $87.84 \%$. But the amount of $\mathrm{CV}$ ions adsorbed per unit mass of adsorbent increased with the increase of the initial $\mathrm{CV}$ concentrations [56]. For OLAC, the equilibrium adsorption capacity increased from $4 \mathrm{mg} / \mathrm{g}$ to $29.3 \mathrm{mg} / \mathrm{g}$. This can be attributed to the effective pore diffusitivity decrease with increasing initial adsorbent concentration $[61,62]$ and to a more efficient utilization of the sorptive capacities of the sorbent due to greater driving force overcoming all mass transfer resistance of the $\mathrm{CV}$ between the aqueous and the solid phases (by a higher concentration gradient pressure), as referred to in literature $[32,41,63,64]$.

\section{The Isotherm Analysis}

The linearized Langmuir and Freundlich isotherms of CV obtained are shown in Fig. 12, and the slopes and the intercepts of these linear plots were used to calculate the constant parameters in both equations of Langmuir and Freundlich isotherms [31, 41, 57]. Considering the values of linear regression coefficients $\left(\mathrm{R}^{2}\right)$, the freundlich isotherm model with $\left(\mathrm{R}^{2}\right)$ of 0.9937 is assumed to be more suitably fitted to the sorption data in the studied CV concentration range compared with Langmuir isotherm model $\left(\mathrm{R}^{2}=0.9746\right)$, although the isotherm parameters of the Langmuir isotherm is also indicating favourable sorptions.

Table 3 shows the calculated constants from the obtained results of Langmuir and Freundlich isotherm equations. Fig. 12 shows that in a plot between $C_{e} / q_{e}$ and $C_{e}$, the Langmuir constants $q_{m}$ representing the maximum capacity, is found to be $41.15 \mathrm{mg} / \mathrm{g}$ while b is $0.4361 / \mathrm{mg}$. Similarly, and from the plot between $\log$ qe and $\log C_{e}$ of a Freundlich isotherm model, the constants $K_{f}$ and $n$ are used to represent the adsorption capacity and the adsorption intensity, respectively. It is well known that the closer the $n$ value to zero, the more heterogeneous the system becomes $[41,65]$. From Table 4 , the calculated $n$ value is found to be 1.60 , indicating that the system is heterogeneous, making it more suitable for a Freundlich isotherm.

\section{Conclusion}

The results of this study show that AC obtained from the withered leaves of Quercus robur Oak Trees (38\%) yield, can be successfully used as a low cost and eco-friendly adsorbent for the removal of $\mathrm{CV}$ from aqueous solution. The adsorption process was influenced by a number of factors such as OLAC adsorbent dose, $\mathrm{pH}$, shaking rate, contact time, and the initial CV concentration. The highest CV removal was obtained at $\mathrm{pH}$ 7.0. The removal efficiency increased with increase in OLAC dose, contact time, and CV initial concentration. The adsorption parameters for the Languimer and Freunlich isotherms were determined and the equilibrium data were best described by the Freundlich isotherm model. The application of these largely abundant OLs in production of such ACs on a large scale will definitely be useful in solving other environmental problems concerning the campus garden of Gdańsk University of Technology and elsewhere. Thus, from an environmental point of view, the benefit of recycling oak leaves in order to obtain activated carbon not only may help the agricultural residue waste disposal problem, but also can be utilized in the treatment of wastewater.

\section{References}

1. ALENI S.J., KOUMANOVA B. Decolourization of Water/Wastewater Using Adsorption, (Review). J. Univ. Chem. Technol. Metalluragy 40, 175, 2005.

2. CHKRABARTI T., SUBRAHMANYAN O.V.R., SUNDARESAN B.B. Biodegradation of Recalcitrant Industrial Wastes, in: Bio-treatment System, Vol II, CRC Press, Inc., Boca Raton, Fl, 1988.

3. SAYAN E. Optimization and Modeling of De-colorization and COD Reduction of Reactive Dye Solutions by Ultrasound-Assisted Adsorption. Chem. Eng. J., 119, 175, 2006.

4. GRAG V.K., KUMAR R., GUPTA R. Removal of Malachite Green Dye from Aqueous Solution by Adsorption Using Agro-industries Waste: a Case Study of Phosppis cineraria. Dyes Pigments, 62, 1, 2004.

5. YOUNG Y., JAIN Y.U. Ligninase-Catalyzed Decolorization. Water Res. 31, 1187, 1997.

6. LIAN L., GUO L., GUO G. Adsorption of Gongo Red from Aqueous Solution onto Ca-Bentonite. J. Hazard. Mater. 161, 126, 2009.

7. HEMA M., ARIVOLI S. Comparative Study on the Adsorption Kinetics and Thermodynamics of Dyes onto Acid Activated Low Cost Carbon. J. Phys. Sci., 2, 10, 2007.

8. ESSAWY A.A., EL-HAG ALI A., ABDEL-MOTALEB M.S.A. Application of Novel Copolymer-TiO ${ }_{2}$ Membrane 
for Some Textile Dyes Adsorptive Removal from Aqueous Solution and Photocatalytic Decolorixation. J. Hazard. Mater. 157, 547, 2008.

9. HASHEM A., AKASHA R.A., GHITH A., HUSSIEN D.A. Adsorbent Based on Agricultural Wastes for Heavy Metal and Dye Removal: a Review. Energy Educ. Sci. Technol. 19, 69, 2007.

10. KAVITHA D., NAMSIVAYAM C. Recycling Coir Pith, an Agricultural Solid Waste, for the Removal of Prcion Orange from Wastewater. Dyes Pigments, 74, 237, 2007.

11. KHATTRI S.D., SINGH M.K. Colour Removal from Synthetic Dye Wastewater Using a Bioadsorbent. Water Air Soil Poll. 120, 283, 2000.

12. OLGUN A., ATAR N. Equilibrium Kinetics Adsorption Study of Basic Yellow 28 and Basic Red [46] by a Boron Industry Waste. J. Hazard. Mater. 161, 148, 2009.

13. NANDI B.K., GOSWAMI A., PURKAIT M.K. Adsorption Characteristics of Brilliant Green Dye on Kaolin. J. Hazard Mater. 161, 387, 2009.

14. EL-NEMR A., ABDEL-WAHAB O., EL-SIKAILY A., KALTED A. Removal of Direct Blue-86 from Aqueous Solution by New Activated Carbon Developed from Orange Peel. J. Hazard Mater. 161, 387, 2009.

15. HAMEED B.H. Spent Tea Leaves: A New Non-Conventional and Low Cost Adsorbent for removal of Basic Dye from Aqueous Solutions. J. Hazard Mater. 161, 753, 2009.

16. SENTHILKUMAR S.P., KALAAMANI K.P., PORKODI P.R. VARADARAJAN C.V. SUBBURAAM. Adsorption of Dissolved Reactive Red Dye from phase onto Activated Carbon Prepared from Agricultural Waste. Bioresource Technol., 971, 1618, 2006.

17. CAMPANELLA A., WOOL R. P., BAH M., FITA S., ABUOBAID A. Composites from Northern Red Oak (Quercus robur) Leaves and Plant Oil-Based Resins, J. Appl. Polym. Sci. DOI:10.1002/app.36663, 2012.

18. BABEL S., KURNIAWAN T.A. Low-Cost Adsorbents for Heavy Metals Uptake from Contaminated Water: a Review. J. Hazard. Mater. 97, 219, 2003.

19. BAILEY S.E., OLIN T.I., BRICKA M., ADRIAN D. A review of Potentionally Low-Cost Sorbent for Heavy Metals. Water Res. 33, 2469, 1999.

20. Activated carbon - Wikipedia, the free encyclopedia.mht

21. TSAI W.T., LEE M.K., CHANG Y.M. Fast Pyrolysis of Rice Straw Sugarcane Bagasse and Coconut Shell in an Inductionheating Reactor. J. Anal. Appl. Pyrolysis 76, 230, 2006.

22. MARTINEZ M.L., TORRES M., GUZMAN C.A., MAESTRI D.M. Preparation and Characteristics of Activated Carbon from Olive Stones and Walnut Shells Ind. Crops Prod. 23, 23, 2006.

23. LIM W.C., SRINIVASAKANNAN C., BALASUBRAMANIAN N. Activation of Palm Shells by $\mathrm{H}_{3} \mathrm{PO}_{4}$ Impregnation for High Yielding Activated Carbon. J. Anal. Appl. Pyrol., 88, 181, 2006.

24. HAIMOUR N.M., EMEISH S. Utilization of Date Stones for Production of Activated Carbon Using Phosphoric Acid. Waste Manage. 26, 651, 2006.

25. ABUDAIA J. A., SULYMAN M. O., EL-EZABY K. Y., BEN-ALI S. M. Adsorption of $\mathrm{Pb}$ (II) and $\mathrm{Cu}$ (II) from Aqueous Solution onto Activated Carbon Prepared from Date Stones. International Journal of Environmental Science and Development, 4, (2), 2013.

26. PRAGYA P., SRIPAL S., MAHESHKUMAR Y. Preparation and Study of Proerties of Activated Carbon Produced from Agricultural and Industrial Waste Shells. Res. J. Chem. Sci. 3, (12), 12, 2013.
27. SULYMAN M. Fixed-bed Column Packed with Low-Cost Spent Tea Leaves for the Removal of Crystal Violet from Aqueous Solution. $5^{\text {th }}$ International Conference on Environmental Science and Technology, IPCBEE 69, 2014.

28. PUTUN E., UZUN B.B., PUTUN A.E. Fixed-bed Catalytic Pyrolysis of Cotton-seed Cake: Effects of Pyrolysis Temperature, Natural Zeolite Content and Sweeping Gas Flow Rate. Bioresour. Technol. 97, (5), 701, 2006.

29. AL-SWAIDAN H. M., ASHFAQ AHMAD. Synthesis and Characterization of Activated Carbon from Saudi Arabian Dates Tree's Fronds Wastes, $3^{\text {rd }}$ International Conference on Chemical, Biological and Environmental Engineering, IPCBEE vol. 20, 2011.

30. CAVAS L., KARABAY Z., ALYURUK H., DOGAN H., DEMIR G.K. Thomas and Artificial Neutral Network Models for the Fixed-Bed Adsorption of Methylene Blue by a Beach Waste Posidonia oceanic L. dead leaves. Chem. Eng. J., 171, 557, 2011.

31. DENIZ, F., KARAMAN S. Removal of Basic Red 46 Dye from Aqueous Solution by Pine Tree Leaves. Chem. Eng. J., 170, 67, 2011.

32. ASHLY L.P, THIRUMALISAMY S. Adsorption of Hazardous Cationic Dyes from Aqueous Solution onto Acacia nilotica Leaves as an Eco Friendly Adsorbent, Sustain. Environ. Res., 22, (2), 113, 2012.

33. BHARATHI K. S., RAMESH S. P.T. Fixed-Bed Column Studies on Bio-sorption of Crystal Violet from Aqueous Solution by Citrullus Lanatus and Cyperus Rotundus. Applied Water Science, DOI 10. 1007/s13201-013-0103-4. Adapted from http://www.Springer.com, 2013.

34. HAN R.P., ZOU W.H., YU W.H., CHENG S.J., WANG Y.F., SHI J. Biosorption of Methylene Blue from Aqueous Solution by Fallen Phoenix Tree`s Leaves. J. Hazard Mater, 141, 156, 2007.

35. EL-SHEIKH A. H., NEWMAN A. P., AL-DAFFAEE H. K., PHULL S., CRESSWELL N. Characterization of Activated Carbon Prepared from a Single Cultivar of Jordanian Olive Stones by Chemical and Physicochemical Techniques. J. Anal. Appl. Pyrol. 71, 151, 2004.

36. HASSLER J. W. Purification with Activated Carbon: Industrial, Commercial and Environmental, Chemical Publishing Company Inc., New York, N.Y, 1974.

37. MATSON J. S., HARRY B M. Activated Carbon: Surface Chemistry and Adsorption from Solution; Marcel Dekker Inc., New York, 1971.

38. NADEEM M., SHABBIR M., ABDULLAH A., SHAH S., MCKAY G. Sorption of Cadmium from Aqueous Solution by Surfactant-Modified Carbon Adsorbents. Chem. Eng. J. 148, 365, 2009.

39. SUBRAMANYAM B., DAS A. Linearized and non-linearized Isotherm Models Comparative Study on Adsorption of Aqueous Phenol Solution in Soil. Environ. Sci. Tech., 6, 633, 2009.

40. HO Y.S. Removal of Copper Ions from Aqueous Solution by Tree Fern. Water Res., 37, 2323, 2003.

41. BHARATHI K.S., RAMESH S.P. Equilibrium, Thermodynamic and Kinetic Studies on Adsorption of a Basic Dye by Citrullus Lanatus Rind. Iranica Journal of Energy and Environment, 3, (1), 23, 2012.

42. SULYMON A. H., MOHAMMED T. J., AL-NAJAR J. Equilibrium and Kinetics Studies of Adsorption of Heavy Metals onto Activated Carbon. Canadian Journal of Chemical Engineering \& Technology, 3, (4), 86, 2012. 
43. ENES SAYAN, An optimization study on removal of $\mathrm{Zn}^{2+}$ from aqueous solution by ultrasound-assisted preparation of activated carbon from alkaline impregnated hazelnut shell. J. Chem. Soc. Pak., 36, (1), 2014.

44. ENES SAYAN, Ultrasound-assisted preparation of activated carbon from alkaline impregnated hazelnut shell:An optimization study on removal of $\mathrm{Cu}^{2+}$ from aqueous solution. Chem. Eng. J. 115, 213, 2006.

45. HOSSAIN M.A., NGUYEN T.V. Biosorption of $\mathrm{Cu}(\mathrm{II})$ from water by banana peel based biosorbent: experiments and models of adsorption and desorption. Jounal of Water Sustainability, 2, (1), 87, 2012.

46. ULAS DURAL M., CAVAS L., PAPAGEORGIOU S. K., FOTIS K. Katsaros, Methylene blue adsorption on activated carbon prepared from Posidonia oceanic (L.) dead leaves: Kinetics and equilibrium studies. Chem. Eng. J. 168, 77, 2011.

47. HAMEED B.H., M.I. EL-KHAIARY. Removal of Basic Dye from Aqueous Solution Using a Noval Agricultural Waste Material: Pumpkin Seed Hull. J. Hazard. Mater., 151, 601, 2008.

48. TAN I.A.W., AHMED A.L., HAMEED B.H. Adsorption of Basic dye Using Activated Carbon Prepared from Oil Palm Shell: Batch and Fixed Bed Studies. Desal., 255, 15, 2008.

49. NORASYIKIN M.M., MOHD A.A.M., YACOB A.R., HASSAN M.A. Physical Activation of Saudi Arabia Date Palm Tree`s Foliar, Frond and Thorn, J. IEEE Explorer, MIMT Jan, China, 2010.

50. KALDERIS D., BETHANIS S., PARAKEVA P., DIAMADOPOULOS E. Production of Activated Carbon from Bagase and Rice Husk by a Single Stage Chemical Activation at Low Retention Times. J. Biores. Technol. 99, 6809, 2008.

51. HAYASHI J., HORIKAWA T., TAKEDA I., FARID N.A. Preparing Activated Carbon from Various Nutshells by Chemical Activation with $\mathrm{K}_{2} \mathrm{CO}_{3}$. Journal of Carbon, 40, 2381, 2002.

52. LI W., PENG J., ZHANG L., YANG K., XIA H., GUO S. Effects of Carbonization Temperatures on Characteristics of Porosity in Coconut Shell Chars and Activated Carbons Derived from Carbonixed Coconut Shell Char. Ind. Crop. Prod. 28, 1085, 2008.

53. SATISH P., VAIJANTA D., SAMEER R., NASEEMS P. Kinetics of Adsorption of Crystal Violet from Aqueous Solution Using Different Natural Materials. International Journal of Environmental Sciences, 1, (6), ISSN 0976-4402, 2011.
54. CHAO H., RUNHU Z., LI L., XIAOYUNG Z. Adsorption of Phenol from Aqueous Solution Using Activated Carbon Prepered from Crofton Weed. Desalination and Water Treatment. 37, 230, 2012.

55. RAMMEL R.S., ZATITI S.A., EL-JAMAL M.M. Biosorption of Crystal Violet by Chaetophora Elegans Algae. Journal of the University of Chemical Technology and Metallurgy. 46, (3), 283, 2011.

56. KUMAR S., JAIN A. Sorptive Removal of Crystal Violet from Aqueous Solution Using Spent Tea Leaves: Part I Optimization of Sorption Conditions \& Kinetics Studies. Acta Chim. Slov., 57, 751, 2010.

57. HASHEMIAN S., ARDAKANI M. K., SALEHIFAR H.. Kinetics and Thermodynamics of Adsorption Methylene Blue onto Tea Waste $/ \mathrm{CuFe}_{2} \mathrm{O}_{4}$ Composite. American Journal of Analytical Chemistry, 4, 1, 2013.

58. KADIRVELU K. NAMASIVAYAN C. Activated Carbon from Coconut Coirpith as Metal Adsorbent: Adsorption of $\mathrm{Cd}(\mathrm{II})$ from Aqueous Solution. Advanced in Environmental Research, 7, 471, 2003.

59. CENGIZ S., CAVAS L. A Promising Evaluation Method for Dead Leaves of Poidonia Oceanic (L.) in the Adsorption of Methyl Violet, Mar. Biotechnol. DOI 10.11007/s/10126010-9260-8, 2010.

60. AWALA H., JAMAL M.M. Equilibrium and Kinetics Study of Adsorption of Some Dyes onto Feldspar, J. Univ. Chem. Technol. Met., (Sofia) 44, 157, 2010.

61. NUHOGLU Y., MALKOC E. Thermodynamic and Kinetic Studies for Environmentally Friendly Ni (II) Biosorption Using Waste Pomace of Olive Oil Factory. Bioresource Technol., 100, 2375, 2009.

62. SKODRAS G., DIAMANTOPOULOU I., PANTOLEONTOS G., SAKELLAROPOULOS. Kinetic Studies of Elemental Mercury Adsorption in Activated Carbon Fixed Bed Reactor. J. Hazard. Mater, 158, 1, 2008.

63. HO Y.S., MCKAY G. The Kinetics of Sorption of Divalent Metal Ions onto Sphagnum Moss Peat. Water Res. 34, 735, 2000.

64. PONNUSAMI V., GUNASEKAR V., SRIVASTAVA S.N. Kinetics of Methylene Blue Removal from Aqueous Solution Using Gulmohar (Delonix regia) Plant Leaf Powder: Multivariate Regression Analysis. J. Hazard. Mater. 169, 119, 2009.

65. HAIRUL NAZIRAH ABDUL HALIM, KELLY LIEW KAR MEE. Adsorption of Basic Red 46 by Granular Activated Carbon in a Fixed- bed Column, IPCBEE vol. 12, IACSIT Press, Singapore, 2011. 